\title{
Crop Pattern Change and Crop Water Requirement Judgment using Remote Sensing and GIS Techniques: a research on Tungabhadra Dam Right Canal
}

\author{
Arunkumar Yadav, Hafeezunnisa, Pramod Kumar Kappadi
}

\begin{abstract}
Agriculture is most important resources of any country worldwide which is a major renewable source and is dynamic. The study area selected was command area under Basavanna canal which is one of the canals to Tungabhadra river on right side bank. This selected canal for cropping pattern analysis has a command of 1240.00 hectare and is located at Vallabhpur, Bellary district. Basavanna canal has a designed discharge capacity of 125 cusecs for serving the cropping area. Every irrigation project has planned cropping pattern, the crop water requirement (CWR) for which is calculated based on Duty/ Delta method. However due to growing population and increase demand for food products crop violation is found in every command leading to more irrigation. Remote Sensing (RS) and Geographical Information System (GIS) techniques have emerged as powerful tools for crop water management. Remotely sensed land use-land cover data was used for analysing the cropping pattern in the area and also to estimate the change in the cropping pattern. This study was performed using ArcGIS 9.3 and ERDAS 9 software. Crop water requirement was calculated using Modified Penman Equation for present cropping pattern. The study finds that, approximately $50 \%$ of water could be saved using modified Penmen method compared to crop water requirement calculated using Duty Delta method as adopted in project report and the same water may be diverted to meet other needs.
\end{abstract}

Index Terms: Crop water requirement, Crop pattern, Crop violation, Remote Sensing and Geographical Information System

\section{INTRODUCTION}

All developed or developing countries has agricultural sustainability as the highest priority. To study the sustainability of agriculture, Cropping System Analysis is essential. Indian society and its economy is based on the agriculture. Majority of Indian farmer's major share of income depends upon crop production. Consequently, to achieve maximum profit it essential to cultivate most suitable crop at the right season. In addition to this, the achievement can be enhanced by studying or examining before selecting a crop for both pre-monsoon season and post-monsoon season [1]. During 1884 importance of crop production information was understood in India [2]. Increasing demand for food and the fact that in canal system initial parts of canal network are supplied by more than sufficient water which causes water shortage for tail end

Revised Manuscript Received on July 10, 2019.

Arunkumar Yadav, P.G. Student, KSRSAC, Visvesvaraya ,

Technological University - Regional Centre Bengaluru, Karnataka, India.

Hafeezunnisa, Assistant Engineer Geometica Department WRDO

Bangalore, Karnataka, India.

Pramod Kumar Kappadi, Research Scholar, National Institute of

Technology -Karnataka, Surathkal, Mangalore, Karnataka, India. regions of canal network. The most suited land for crop cultivation has been spoiled due to over irrigation. It has led to the cultivation into least suited areas which is naturally more delicate. All these changes have unbalanced and destroyed natural ecosystems. Due to this natural populations of flora and fauna is been towards endangers (FAO 1980). To meet the water supply for all regions, crop water requirement must be calculated. To carry out irrigation assessment, the required data consist of discharge measurements, crop irrigation water requirements, effective rainfall, actual evapo-transpiration, irrigated area, cropping intensity and crop yield among others [3].

Development of irrigation largely depends upon water resources, but limitation of water resources causes the irrigation. At the same time, large amount of fertilizer used during cultivation affected the quality of land and water resources and quality of crop yield [4].

The involvement of new approach with new technology is necessary at the earliest (FAO 1980). Traditional systems must be preserved and strengthened wherever possible. First step is evaluation of land use and land cover of Kharif and Rabi season. The latest, popular and user-friendly technology RS and GIS technique is also used for land evaluation. Remote sensing imagery has an application in predicting yield on small scale agriculture and mainly used to estimate crop area and classify different crop categories, [5]. Now a day in agriculture, remote sensing techniques are widely used. Remote sensing gathers a huge data sets over a large area with regular observation. RS provides seasonal data which could be useful in agriculture [6]. Almost all of the applications of remote sensing to date have been based on observing crops in distinct areas of the electromagnetic spectrum. According to seasonal change the spectral signature for vegetation has extreme variation. Hence, to carry out crop identification by remotely sensed data a several data sets like spatial, spectral and temporal have been used over the years $[7,8]$. To carry out irrigation management study, the cloud-free SPOT and Landsat images were used [9]. RS and GIS are a powerful tool with less time consumption provides required output. This tool has a helpful application in almost all area. The present study is an attempt to develop an LULC map of the study area, using IRS LISS-III satellite data for Khariff and Rabi

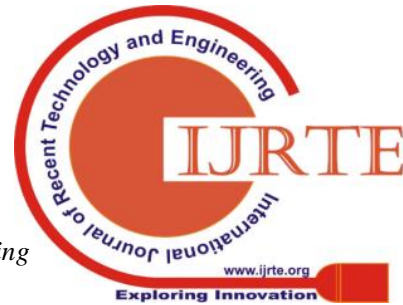




\section{CROP PATTERN CHANGE AND CROP WATER REQUIREMENT JUDGMENT USING REMOTE SENSING AND GIS TECHNIQUES: A RESEARCH ON TUNGABHADRA DAM RIGHT CANAL}

season. Further analysis of cropping pattern and crop water requirement studies carried out for Basavanna canal of Tunga bhadra right bank. Later obtain results linked to develop the needful water supply.

\section{STUDY AREA}

The river Tungabhadra is a major tributary to River Krishna and is so called after the confluence of the two rivers Tunga and Bhadra. This rises in the Western Ghats at an elevation of nearly 1198 Mts above mean sea level. The Tungabhadra River flows for about $531 \mathrm{Kms}$ in the NorthEastern direction through Karnataka State and Andhra Pradesh before it joins, Krishna River near Kurnool at an elevation of 294.10 Mts.

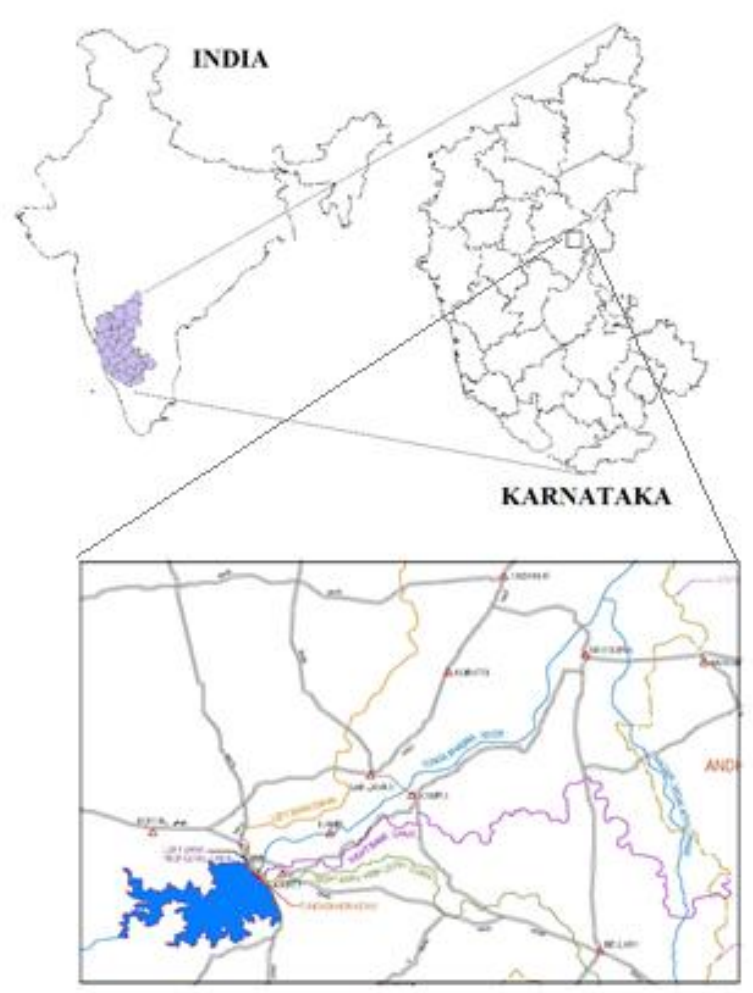

Fig 1. Study Area Location

The vast drainage area of Tungabhadra River comprises of the following main tributaries (a) Kumadvathi River (b) Dharma River (c) Varada River (d) Dodda halla (e) Murdha halla (f) Haridhra river. The Vijayanagara Channel system is spread over 3 districts namely Bellary, Raichur and Koppal. The Geographical area lies between a latitude of $14^{\circ} 30^{\prime}$ to $16^{\circ} 34^{\prime} \mathrm{N}$ and Longitude of $75^{\circ} 40^{\prime}$ to $77^{\circ} 35^{\prime} \mathrm{E}$. Vijaynagara Channels are the run of the River Irrigation Channels in its original form and are built during Vijayanagara Dynasty about 400 years ago. In all, there are 19 Channels taking off from Tungabhadra River of which 18 are in Karnataka and one is in Andhra Pradesh. Basavanna canal is one among the 18 channels.

Table 1. List of Channels (Source: E I Technologies Pvt. Ltd)

\begin{tabular}{cc}
\hline $\begin{array}{c}\text { On Right Bank of TB } \\
\text { River }\end{array}$ & $\begin{array}{c}\text { On Left Bank of TB } \\
\text { River }\end{array}$ \\
\hline 1. Raya & 11. Koregal \\
\hline
\end{tabular}

\begin{tabular}{ll}
\hline 2. Basavanna & 12. Hulugi \\
3. Bella & 13. Shivapura \\
4. Kalaghatta & 14. Anegundi \\
5. Turtha & 15. Gangavathi Upper \\
6. Ramasagar & 16. Gangavathi Lower \\
7. Kampli & 17. Bichal \\
8. Belagodhala & 18. Bennur \\
9. Deshnur & \\
10.Siraguppa & \\
\hline
\end{tabular}

\section{DATA}

Satellite data can be used as a basic data source for crop system mapping. Indian Remote Sensing Satellite Resourcesat (IRS-P6) LISS (Linear Imaging Self Scanning Sensor) III data is consisted of spatial and temporal resolution. The sensor provides $23.5 \mathrm{~m}$ spatial resolution data in Green, Red, NIR and SWIR bands with 24 days revisit capability. The repetition cycle may be used for deriving Kharif, Rabi and summer cropping pattern and change analysis between these seasons. In the present study Remote sensing data from sensor LISS III (IRS-P6) of 201112 were used to analyze the cropping pattern and crop rotation for Kharif and Rabi seasons.

Table 2. shows details of remote sensing data used for the study. Plate shows the image obtained from IRS 1D LISS III for the Year 2011 and 2012.

\begin{tabular}{lllllll}
\hline Sl. No & $\begin{array}{l}\text { Name of } \\
\text { Satellite }\end{array}$ & Sensor & Path & Row & Product & $\begin{array}{l}\text { Date of } \\
\text { pass }\end{array}$ \\
\hline 1 & IRS-1D & LISS III & 97 & 63 & $\begin{array}{l}\text { Geocoded } \\
\text { FCC }\end{array}$ & Dec 2011 \\
2 & IRS-1D & LISS III & 97 & 63 & $\begin{array}{l}\text { Geocoded } \\
\text { FCC }\end{array}$ & Feb 2012 \\
\hline
\end{tabular}

The monthly rainfall data pertaining to Munirabad and Kamalapur 2 rain gauge stations which have a bearing on the irrigation water requirement were collected from the Water Resources Development Organization (WRDO) for the period 1980 to 2009 (30 years).

The Survey of India (SOI) topomap surveyed during 1976 and 1979 was used for digitising the base map of the study. The topomap the physical features of the land including the contour, general type of vegetation and water, and also shows man-made features such as administrative boundaries, roads, utilities and structures. These are the basic maps on which the satellite images are geo-referenced, and are utilized at every level of image analysis and ground sampling. The topomap that was used for the analysis of the area of interest is 57A/07 1:50000 scale.

\section{METHODOLOGY}

\section{A. Crop patterns change analysis}

The IRS-LISS III satellite imagery of both season dated 2011 and 2012 such as kharif and Rabi season respectively was used for present study. This data was used to derive

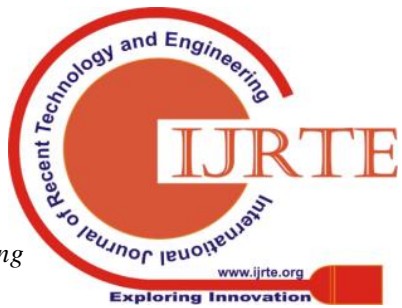


Land use and Land cover of Basavanna canal for kharif and Rabi season in terms of crops. Supervised classification using Non-Parametric Classifiers, for this analysis Erdas Imagine 9.3 tool used. To carry out this classification ground truth data was collected using GPS enabled camera and this helped to assign spectral signature for different crops at the study area. The ground truth data in terms of field visit photographs as shown in figure 2. Using spectral signature, the training sets are assigned for the different signatures, these training sets are essential for image classification. Further using Arc GIS tool, the LU/LC mapping has been done which contains attributes, areas and so on.

\section{B. Ground truth of study area}

In this study the ground truth is collected with the GPS points. Hence it is useful for the Supervised classification. While collecting the ground truth, it was observed that, tail end reaches of canal had less water supply. Generally, also found that in some fields water supply was more than needed in case of crops grown in the field, it was observed that majorly almost all land was sown with sugarcane which is a perineal crop and on other hand crop field surrounded by coconut tree. Some of the land were growing light crop such as mustard.

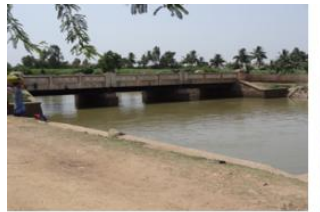

a) Basavana canal

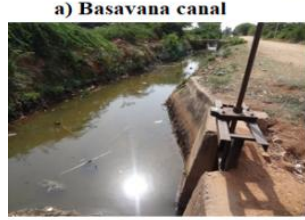

c) Canal Regulater

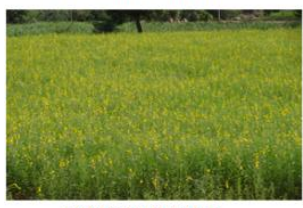

e) Mustard Crop

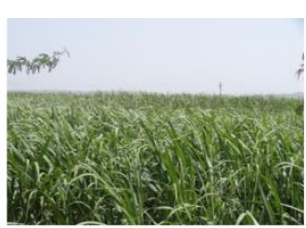

b) Sugarcane Crop

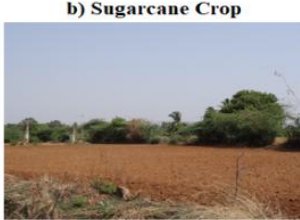

d) Cultivation land

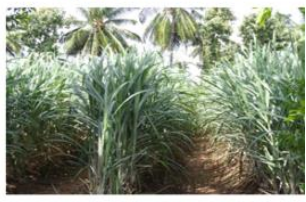

f) Sugarcane and Coconut

Fig. 2. Field visit photographs

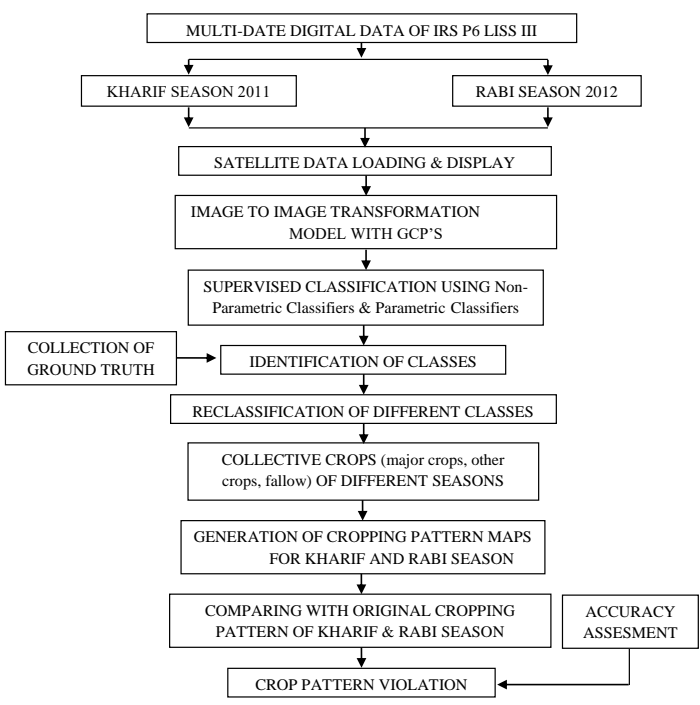

Fig.3.Flow chart of methodology

\section{Determining crop water requirement using modified Penman method}

Water is essential for crop production and best use of available water must be made use for optimizing production and securing high yields. Therefore, efficient use of water in crop production can only be attained by proper planning and management to meet water requirement in proper quantity and time for optimum growth and high yields of the crop. The crop water requirement depends on;

1. Climate or the ambient environment (in hot climate crops need more water per day than in cloudy and cool climate).

2. Crop genity type (crops having large leaf need more water than crops have small leaf area).

3. Crop growth stages.

D. Procedure for calculation of Crop Water Requirement using modified Penman method

$$
\mathbf{E T}_{\mathbf{C}}=\mathbf{E T}_{\mathbf{O}} \times \mathbf{K}_{\mathrm{C}}
$$

Where, $\mathrm{ET}_{\mathrm{C}}=$ Crop evapo-transpiration in $\mathrm{mm} /$ day

$\mathrm{ET}_{\mathrm{O}}=$ Reference crop ET in $\mathrm{mm}$ /day which represents the rate of ET from an extensive surface of 8 to $15 \mathrm{~cm}$ tall, green grass cover of uniform height actively growing completely shading the ground and not short of water. To calculate $\mathrm{ET}_{\mathrm{O}}$, the meteorological data for minimum 10 days are required.

\section{$K_{C}=$ Crop Co-efficient}

\section{RESULTS}

\section{Crop pattern Analysis}

Cropping pattern analysis has been done for the study area considering 2011-12 imagery for Khariff and Rabi season. Using ERDAS IMAGINE 9.3 tool the image classification is made for the said imagery. Depending on the colour tone and ground truth the crops are classified and the LU/LC map has been generated for Kharif and Rabi season. LU/LC comparison of Kharif and Rabi season shows in Fig.3 to Fig.6.

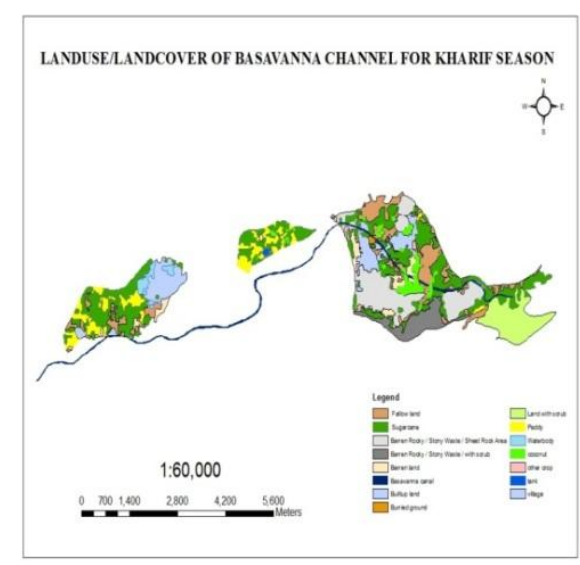

Fig. 3. Land use/Land cover of Basavanna Channel for Kharif season 2011 


\section{CROP PATTERN CHANGE AND CROP WATER REQUIREMENT JUDGMENT USING REMOTE SENSING AND GIS TECHNIQUES: A RESEARCH ON TUNGABHADRA DAM RIGHT CANAL}

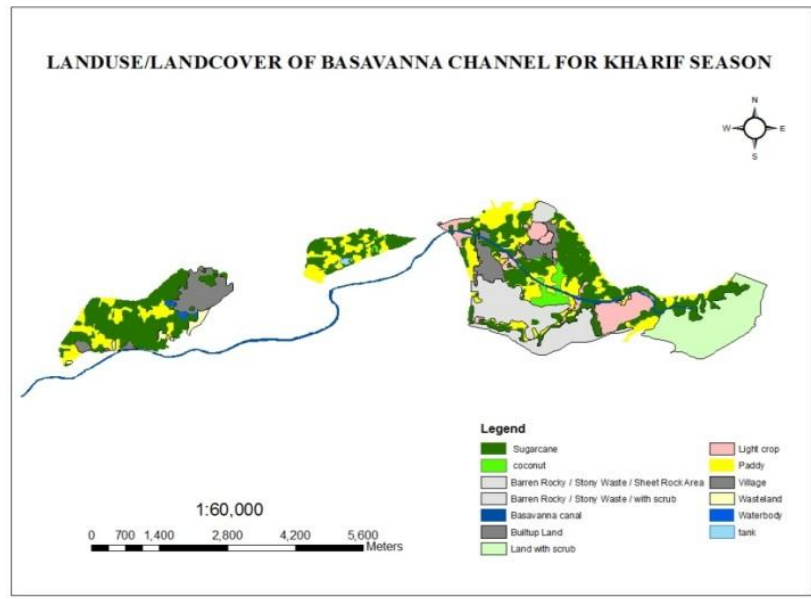

Fig. 4. Land use/Land cover of Basavanna Channel for planned Kharif season 2011

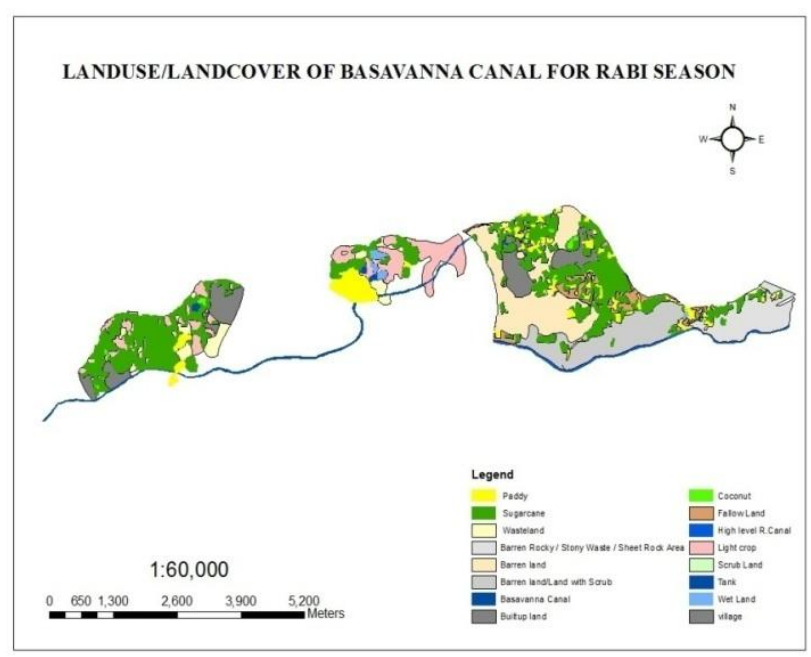

Fig. 5. Land use/Land cover of Basavanna Channel for for Rabi season 2012

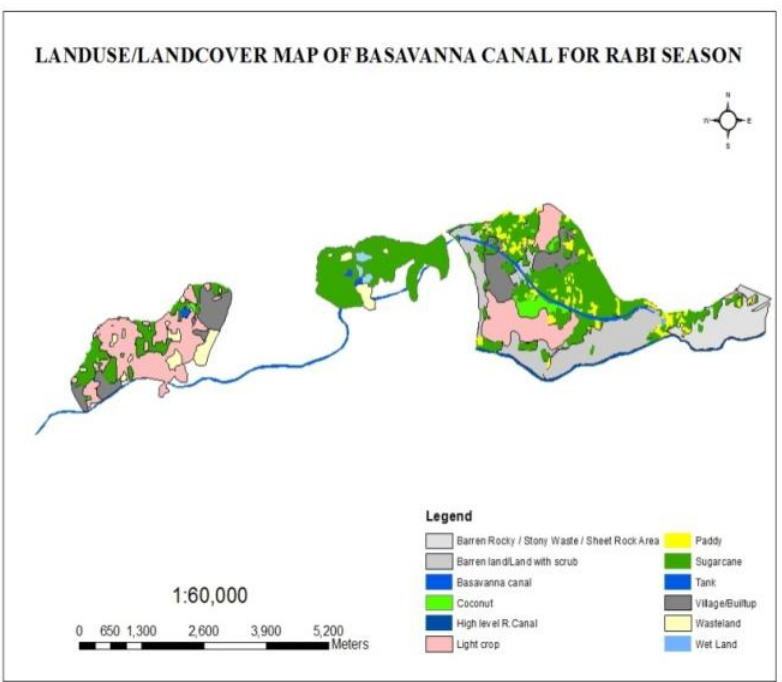

Fig. 6. Land use/Land cover of Basavanna Channel Planned Rabi season2012
Table 3. Change in cropping pattern and other LU/LC features for Khariff season.

\begin{tabular}{lll}
\hline $\begin{array}{l}\text { Crop \& Other } \\
\text { LU/LC Features }\end{array}$ & $\begin{array}{l}\text { PLANNED } \\
\text { Area } \\
\text { (HA) }\end{array}$ & $\begin{array}{l}\text { AS } \\
\text { IMAGERY } \\
(\mathbf{2 0 1 1 - 1 2}) \\
\text { Area in (HA) }\end{array}$ \\
\hline Coconut & 33.289 & 58.063 \\
Fallow land & 0.000 & 194.143 \\
Sugarcane & 598.678 & 510.082 \\
Paddy & 287.148 & 187.973 \\
Light crop & 120.364 & 9.069 \\
Tanks & 2.808 & 2.486 \\
Villages \& Built-up & 152.748 & 169.318 \\
Waste lands & 57.301 & 15.930 \\
Barren Rocky / Stony & 112.120 & 228.332 \\
Waste / Sheet Rock & & \\
Area & & \\
Land with Scrubs & 100.729 & 246.278 \\
Barren land & 167.858 & 40.576 \\
Wet lands & 29.207 & 0.000 \\
River/Streams & 24.750 & 24.750 \\
\hline
\end{tabular}

Table 4. Change in cropping pattern and other LULC features for Rabi season

$\begin{array}{ccc}\begin{array}{c}\text { Crop \& Other LU/LC } \\ \text { Features }\end{array} & \text { PLANNED } & \begin{array}{c}\text { AS PER } \\ \text { IMAGERY } \\ \text { (2011-12) }\end{array} \\ \text { Coconut } & 33.289 & 58.063 \\ \text { Area in (HA) }\end{array}$

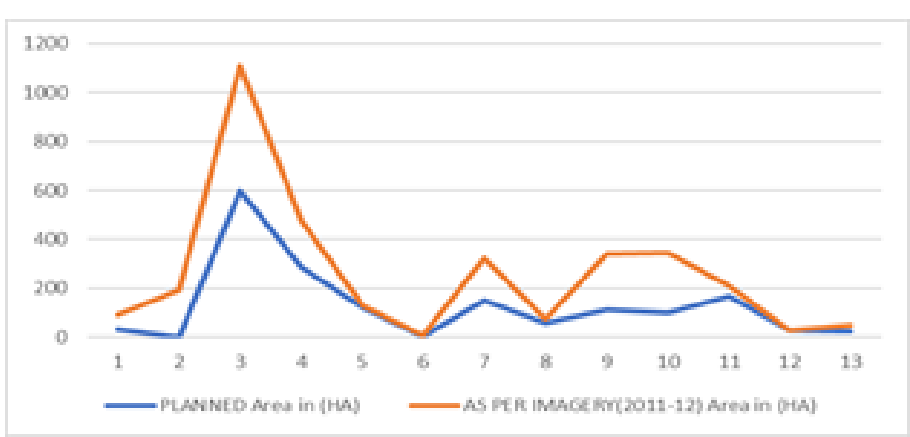

Fig. 7. Shows comparison between Planned and imagery for Kharif season

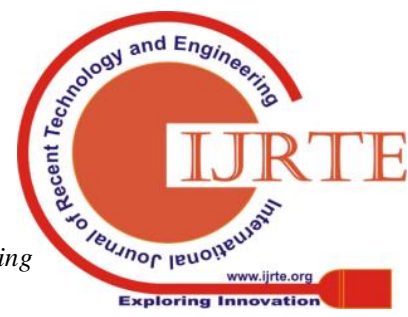




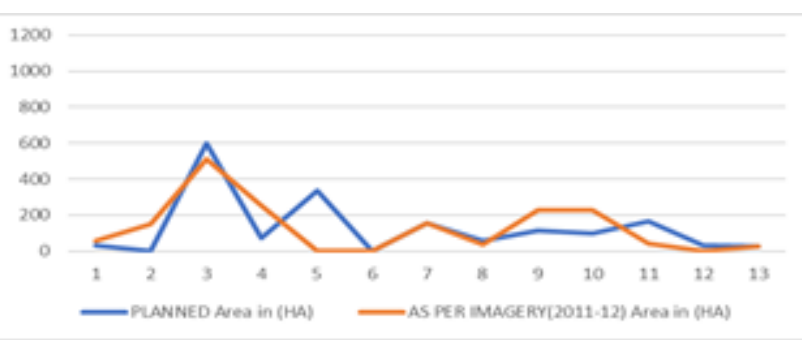

Fig. 8. Shows comparison between Planned and Imagery for Rabi season

It is observed that during Khariff season as per planned cropping pattern light crop is $120.364 \mathrm{Ha}$ however as per imagery light crops cultivated during the season is $9.069 \mathrm{Ha}$, likewise there is change in every crop area, like coconut, sugarcane, paddy. Also, it is observed from imagery that there is fallow land to a tune of $194.143 \mathrm{Ha}$ and there is change in built up area. Likewise, it is observed during the Rabi season that there is major increase in area of paddy as compared to planned paddy area. However, there are no light crops cultivated during Rabi season as proposed.

\section{Crop water requirement}

- Using modified Penman method arrived CWR for the study area is $0.46 \mathrm{TMC}$

Table 5. Crop water requirement using duty and delta method

\begin{tabular}{lcccc}
\hline $\begin{array}{l}\text { Name of } \\
\text { the crop }\end{array}$ & $\begin{array}{l}\text { Base } \\
\text { period }\end{array}$ & $\begin{array}{l}\text { Area in } \\
\text { acres }\end{array}$ & $\begin{array}{l}\text { CWR } \\
\text { (Mcft) }\end{array}$ & CWR(TMC) \\
\hline $\begin{array}{l}\text { Kharif } \\
\text { Paddy }\end{array}$ & 135 & 709.26 & 165.46 & 0.17 \\
$\begin{array}{l}\text { Perenial_ } \\
\text { Sugarcane }\end{array}$ & 304 & 1478.72 & 456.93 & 0.46 \\
$\begin{array}{l}\text { Rabi } \\
\text { Paddy }\end{array}$ & 151 & 173.21 & 45.20 & 0.05 \\
$\begin{array}{l}\text { Kharif } \\
\text { Light }\end{array}$ & 122 & 308.27 & 32.49 & 0.03 \\
$\begin{array}{l}\text { Rabi } \\
\text { Light }\end{array}$ & 120 & 843.23 & 87.43 & 0.09 \\
$\begin{array}{l}\text { Perenial_ } \\
\text { Coconut }\end{array}$ & 365 & 82.23 & 7.10 & 0.07 \\
\hline Total & & & & 0.86 \\
\hline
\end{tabular}

Table 6. Crop water requirement using Modified Penman method

\begin{tabular}{lcccc}
\hline Name of the crop & $\begin{array}{l}\text { Base } \\
\text { period }\end{array}$ & $\begin{array}{l}\text { Area in } \\
\text { acres }\end{array}$ & $\begin{array}{l}\text { CWR } \\
\text { (Mcft) }\end{array}$ & $\begin{array}{l}\text { CWR } \\
\text { (TMC) }\end{array}$ \\
\hline Kharif Paddy & 135 & 709.26 & 91.21 & 0.17 \\
& & & & \\
Perenial_Sugarcane & 304 & 1478.72 & 249.14 & 0.25 \\
Rabi Paddy & 151 & 173.21 & 26.78 & 0.03 \\
& & & &
\end{tabular}

\begin{tabular}{lcccc}
\hline Kharif Light & 122 & 308.27 & 12.2 & 0.01 \\
Rabi Light & 120 & 843.23 & 65.5 & 0.07 \\
Perenial_Coconut & 365 & 82.23 & 17.34 & 0.02 \\
\hline Total & & & & 0.46 \\
\hline
\end{tabular}

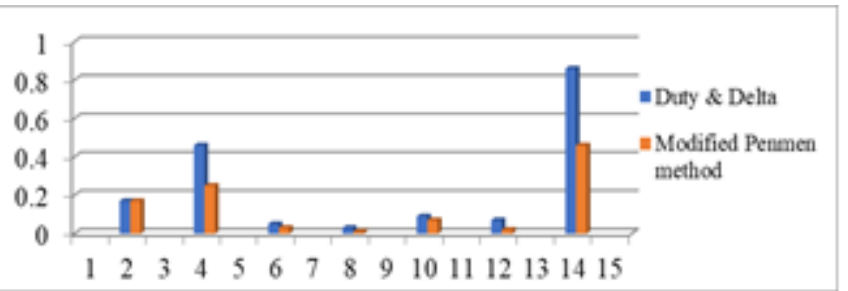

Fig. 9. Shows difference between Duty, Delta and Modified Penman method

\section{CONCLUSION}

Image classification technique was used for LISS-III data to prepare the land use / land cover map to derive the crop pattern change analysis and to estimate the Crop Water Requirement. However, the accuracy of crop pattern change can be improved by using three seasons data and multi-year satellite data with the accuracy of digital interpretation, image enhancement of remotely sensed data. Land use / land cover and other information were considered only for two seasons. Hence, it needs timely updating of land use / land cover and other thematic information of three season for accurate crop pattern change analysis. Also, higher version of LISS-III images should be used for the analysis Complete database creation of the irrigation canals details are required for respective dams, which can be used for the improvement of the canals and also should contain information about the cropping pattern system the particular canal. Also, land capability analysis can be carried out for different cropping system depending upon the potential of natural resources. The digital data base created by Arc GIS and image techniques used by Erdas imagine software's, this can be used for better management of cropping pattern system for irrigation canals. Crop Water Requirement is the important parameter. At present the existing systems are based on Duty and Delta method. Using this method, the crop water requirement was found to be 0.86 TMC. We found that by using modified Penmen method, the crop water requirement was found to be $0.46 \mathrm{TMC}$, which approximately $50 \%$ of water. For CWR calculation the areas are considered from LULC kharif and rabi season respectively. As urban development is cruising, which has drinking water problem, the saved water could be diverted to drinking or another house hold needs. Water Resource Departments of India and in Government sectors, these concepts are being adopted. By using modified penmen method, huge amount of water can be saved and used for other purpose. This method of CWR and Crop pattern change analysis will be helpful for the Government sectors. 


\section{CROP PATTERN CHANGE AND CROP WATER REQUIREMENT JUDGMENT USING REMOTE SENSING AND GIS TECHNIQUES: A RESEARCH ON TUNGABHADRA DAM RIGHT CANAL}

\section{REFERENCES}

1. Manjunath K R (2006) Remote sensing and GIS applications for crop systems analysis. Invited lecture delivered during NNRMS Training Programme on "Geoinformatics for Sustainable Development" at, Haryana Remote Sensing an applications Centre, Hisar, India.

2. Bishnoi S, Sharma M P, Prawasi R, Hooda R S (2014) Geospatial Approach for Cropping System Analysis: A Block Level Case Study of Hisar District in Haryana. In Landscape Ecology and Water Management 2014 Springer, Tokyo

3. Bastiaanssen W G, Bos M G (1999) Irrigation performance indicators based on remotely sensed data: a review of literature. Irrigation and drainage systems 13(4):291-311

4. Xinchun C, Mengyang W, Rui S, La Z, Dan C, Guangcheng S, Shuhai T (2018) Water footprint assessment for crop production based on field measurements: A case study of irrigated paddy rice in East China. Science of the Total Environment 610:84-93

5. Kanemasu E T (1974) Seasonal canopy reflectance patterns of wheat, sorghum, and soybean. Remote Sensing of Environment 3(1):43-47

6. Atzberger C (2013) Correction: Atzberger, C. Advances in Remote Sensing of Agriculture: Context Description, Existing Operational Monitoring Systems and Major Information Needs. Remote Sensing 5(8):949-981

7. Byeungwoo J, Landgrebe DA (1992) Classification with spatio-temporal interpixel class dependency contexts. IEEE Trans Geosci Rem Sens 30(4):663-672

8. Wharton SW (1982) A contextual classification method for recognizing land use patterns in highresolution remotely sensed data. Pattern Recogn 1(4):317-324

9. Moran M S (1994) Irrigation management in Arizona using satellites and airplanes. Irrigation Science 15(1):35-44 